\title{
Sedm otazníků v léčbě hypertenze
}

Sympozium hlavního sponzora výročního XXIX. kongresu České kardiologické společnosti bylo zaměřeno na léčbu hypertenze. Prof. MUDr. Aleš Linhart, DrSc., a prof. MUDr. Michal Vrablík, Ph.D., se podrobně zabývali cílovými hodnotami krevního tlaku pohybujícími se mezi 120 a 140 mm Hg STK, potřebou jeho rychlého sní̌ení do 3 měsíců od zjištění hypertenze i tématem kombinované léčby. Ta by měla být nasazena již při zahájení léčby nejlépe kombinací blokátoru systému renin-angiotenzin a blokátoru kalciového kanálu s prìdáním diuretika ve 2 . kroku a preferenčně s využitím fixních kombinací. Rozebrali také výběr diuretika, kdy se shodli, že indapamid je diuretikum s př́znivým metabolickým profilem, dlouhým poločasem a dobrým účinkem na snižení krevního tlaku, které v běžných dávkách vykazuje minimální riziko minerálových dysbalancí. V závěru poukázali na potřebu správného měření tlaku a prokázaný př́nos domácího monitoringu krevního tlaku, optimálně spojeného s telemedicínou pro zlepšení kompenzace hypertenze, které by mohlo být, zvláště po zkušenostech z období covidových restrikcí, zavedeno do běžné praxe.

\section{Kde máme v ČR problém v kardiovaskulární prevenci?}

ČR je stále mezi zeměmi s nejvyšší incidencí kardiovaskulárních (KV) onemocnění. Trendy KV rizikových faktorů za posledních 30 let dle studie post-MONICA ukazují pokles průměrného systolického (STK) a diastolického tlaku krve (DTK) ve vyšších věkových kategoriích nad 55 let, ovšem u jedinců ve věku 25-45 let STK i DTK stagnuje nebo dokonce stoupá (1). Hypertenze jako jeden z významných ovlivnitelných KV rizikových faktorů není vyřešeným problémem. Při současném výskytu více KV rizikových faktorů se riziko KV př́hod nesčítá, ale násobí. Hypertenze je často provázena dyslipidemií a dalšími KV rizikovými faktory a všechna tato rizika je třeba řešit současně.

\section{Proč je třeba snížit krevní tlak rychle?}

V poslední době se v kompenzaci KV rizikových faktorů stává aktuální otázka času. Aktuální doporučení uvádějí nejen cílové hodnoty léčby hypertenze, ale také časový úsek, kdy je třeba těchto cílů dosáhnout. Důkazy o prínosu snížení krevního tlaku (TK) u pacientů s hypertenzí jsou velmi rozsáhlé. Metaanalýza 123 studií s více než půl milionem účastníků potvrdila, že pokles TK o $10 \mathrm{~mm}$ Hg je spojen s poklesem rizika velkých KV př́hod (MACE) o 20\% a rizika srdečního selhání o $28 \%$ (2). Důvod, proč bychom měli zahájit léčbu hypertenze co nejdřive po jejím zjištění, zejména v případě vyšších stupňů hypertenze (obr. 1) (3), je doložený brzký

Obr. 1. Časový aspekt léčby hypertenze dle aktuálních doporučení (3)

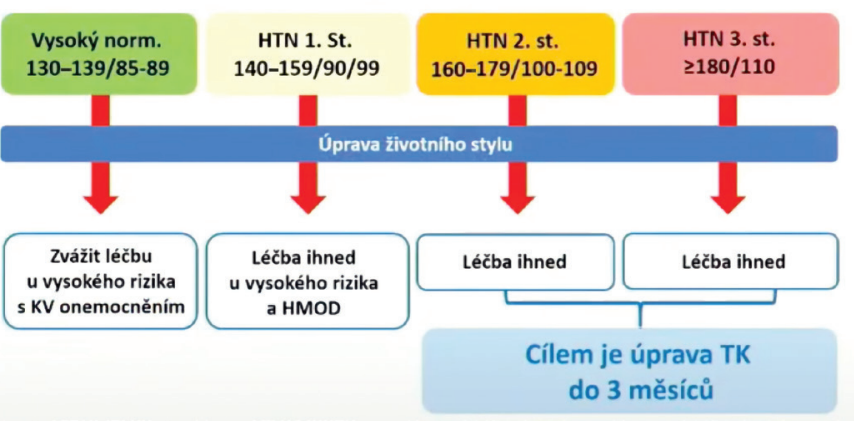

rozdíl (během prvních 6 měsíců) ve výskytu první KV príhody v závislosti na dosaženém sní̌ení TK, jak např. ukázala již v roce 2004 studie VALUE (4).

U pacientů s nově diagnostikovanou hypertenzí můžeme při časné intervenci dosáhnout velmi výrazného efektu, protože zasahujeme ještě před stadiem rozvinutých ireverzibilních cévních změn. K nejrychlejšímu nárůstu rizika KV príhod dochází během prvních měsíců po diagnóze hypertenze (obr. 2) (5). Jde tedy o období, kdy lze do rozvoje KV rizika časnou intervencí nejvýrazněji zasáhnout. Dlouhodobá sledování navíc ukázala, že u hypertoniků s pozdějším snižením TK není již nikdy dosaženo takového poklesu KV rizika jako u pacientů s časným dosažením kompenzace hypertenze.

\section{Kam až snižovat krevní tlak?}

Výsledky studií TRANSCEND a ONTARGET, které společně zahrnuly přes 56000 pacientů, ukázaly nejnižší riziko KV príhod (úmrtí z KV přičin, infarkt myokardu [IM], cévní mozková príhoda [CMP], hospitalizace pro srdeční selhání [SI]) a nejnižší KV mortalitu při hodnotách STK 120-140 mm $\mathrm{Hg}$ (obr. 3) (6).

Cílové hodnoty TK by měly být individualizované. Podle aktuálních evropských a českých doporučení pro léčbu hypertenze z roku 2018 je u pacientů s hypertenzí ve věku 18-65 let první cílovou hodnotou TK < 140/90 mm Hg. Pokud pacient toleruje další snížení, může být cílem hodnota TK kolem 130/80 mm Hg. STK by ale zpravidla neměl

Obr. 2. Kardiovaskulární riziko stoupá nejrychleji krátce po vzniku hypertenze (dle 5)

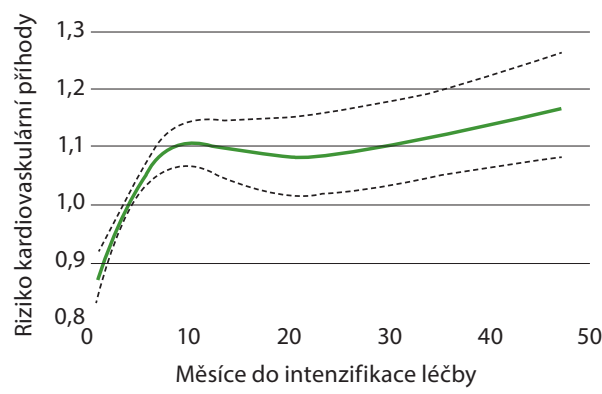

$\mathrm{N}=88756$ nemocných z databáze primární péče $v$ UK

Sledování 37, 4 měsíce, celkem 9985 KV príhod 
Obr. 3. Hodnoty STK spojené s nejnižším KV rizikem (úmrtí z KV príǐin, IM, CMP, hospitalizace pro srdečníselhání) (dle 6)

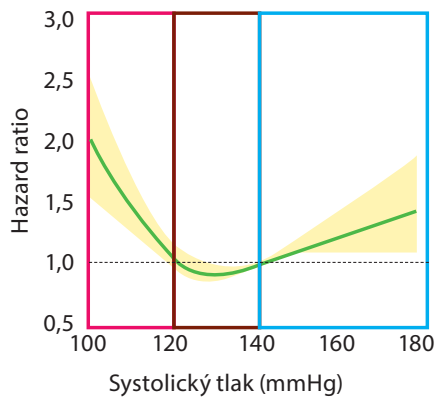

Potenciální negativní dopad

Optimální korekce rizika

Vysoké riziko

klesnout pod 120 mm Hg. U pacientů starších 65 let jsou cílové hodnoty podobné, i když bychom měli být ve snižování TK konzervativnější a udržet STK $\geq 130 \mathrm{~mm} \mathrm{Hg}$ (3). V léčbě hypertenze se tedy bráníme přiliš agresivnímu snižování TK na rozdíl od snižování jiného KV rizikového faktoru, LDL cholesterolu, kde nebyla riziková nejnižší hladina dosud nalezena.

Kontrolu dosažení tohoto okna cílové hodnoty STK ztěžují různé výsledky u různých způsobů měření krevního tlaku a také vysoká variabilita TK, zejm. u pacientů s hypertenzí. Pacienty je tedy třeba edukovat, že domácí měření by měli provádět opakovaně a za validní považovat výsledek několikadenních kampaní měření, že u 24hodinového monitorování je důležitá průměrná hodnota. Vysoká variabilita TK je ovšem sama o sobě také informací poukazující na zvýšené KV riziko u daného pacienta. Lze ji snížit nejlépe podáváním blokátorů kalciových kanálů (BKK) a diuretik a často jsou nutné kombinace antihypertenziv.

\section{Proč je třeba zahájit léčbu hypertenze fixní kombinací?}

Farmakoterapie hypertenze je průkopníkem kombinované léčby a využivání fixních kombinací v KV medicíně. Podle současných doporučení je již v 1. kroku léčby hypertenze na místě dvojkombinace antihypertenziv a ve 2. kroku trojkombinace, v obou prípadech nejlépe v jediné tabletě (3). Toto doporučení vychází z výsledků studií, které ukázaly že 75-80\% hypertoniků potřebuje kombinovanou léčbu. Bylo také doloženo, že kombinace 2 antihypertenziv je při snižování TK 5 X úspěšnější než dvojnásobná dávka 1 antihypertenziva (7). Jde již o všeobecně akceptovaný prístup, který vede ke stále častějšímu využívání fixních kombinací. Použití fixních kombinací prokazatelně zvyšuje adherenci k léčbě (8), což je důležitý prínos vzhledem k velmi špatnému a v čase klesajícímu dodržování KV preventivní léčby ze strany pacientů (9).

Pro časné zahájení kombinované léčby hypertenze s využitím fixních kombinací svědčí i doložený fakt, že časná kombinovaná terapie je v porovnání s postupným nasazováním antihypertenziv spojena s nižším rizikem KV príhod, jako je IM, CMP nebo hospitalizace pro srdeční selhání, a to až o polovinu. Tyto výsledky i klinická praxe vyvracejí počáteční obavy z fixních kombinací v podobě absence možnosti individualizované titrace jednotlivých molekul, rozlišení léčiva vyvolávajícího nežádoucí účinky či situace, kdy vynechání 1 tablety znamená vynechání 2 účinných látek.
Obr. 4. Postup kombinovanéléčby hypertenze podle aktuálních doporučení (3)

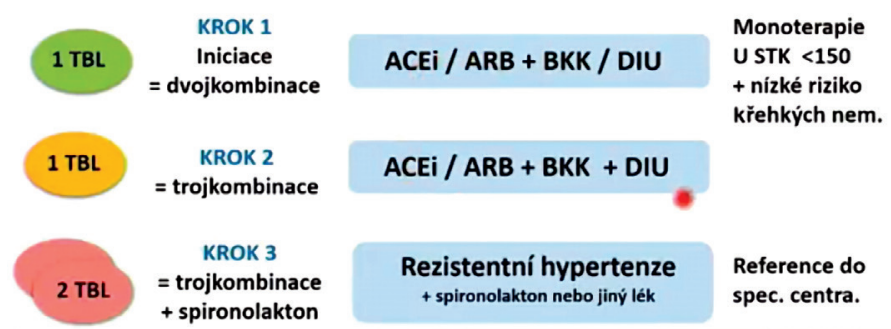

$A C E i=$ inhibitor angiotenzin konvertujicího enzymu, $A R B=$ blokátor receptoru pro angiotenzin 2, BKK = blokátor kalciového kanálu, DIU = diuretikum, STK= systolický krevnítlak

\section{Proč je nejpozději ve 2. kroku léčby hypertenze třeba přidat diuretikum?}

Přesnou patofyziologii vzniku hypertenze u jednotlivých pacientů neznáme. U většiny z nich je ale nadměrně aktivován systém renin-angiotenzin (RAS), proto je na místě v první řadě volit mezi tř́dami antihypertenziv léky blokující tento systém. V prvním kroku je opodstatněné také podávání BKK, které díky svému nespecifickému vazodilatačnímu účinku vykazuji efekt bez ohledu na patofyziologický mechanismus vzniku hypertenze u daného pacienta. Inhibitory angiotenzin konvertujícího enzymu (ACEI) a BKK se navíc ve svých účincích potencují a jsou metabolicky šetrné.

Nejčastější príčina rezistence na léčbu hypertenze je absence diuretika ve farmakoterapii. Diuretikum by tedy mělo být nejpozději třetím nasazeným antihypertenzivem v kombinaci. I zde jsou k dispozici fixní kombinace. Studie dokládají, že přidání diuretika vede k významnému zvýšení podílu pacientů s dosažením cílových hodnot TK (11). Přidání diuretika ve 2. kroku léčby hypertenze je uvedeno i v oficiálních doporučeních pro léčbu hypertenze (obr. 4) (3).

Důvody doporučeného časnějšího nasazení blokátorů RAS a BKK před diuretikem vycházejí mimo jiné z výsledků studie ACCOMPLISH, která ukázala, že kombinace ACEl benazeprilu s BKK amlodipinem prodlužuje dobu do první KV přihody v porovnání s kombinací stejného ACEl a hydrochlorthiazidu (HCTZ), (obr. 5) (12). Kombinace ACEl a BKK v porovnání s kombinací ACEl a HCTZ významně snižila výskyt složeného sledovaného parametru zahrnujícího úmrtí z KV príčin, IM a CMP, ale i kombinovanou KV a celkovou mortalitu a potřebu první revaskularizace (12). U nekompenzovaných pacientů vede přidání diuretika v dalším kroku léčby k významnému snížení TK.

Obr. 5. Delší doba do výskytu KV př́hod při léčbě hypertenze $A C E I+B K K$ vporovnánís ACEI + diuretikem (12)

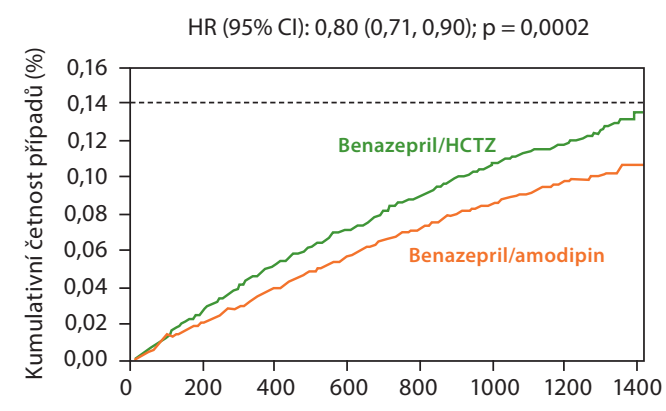

Doba do první KV příhody 
Diuretika mají i doložený prínos na snížení mortality. Dostatek důkazů je k dispozici u chlortalidonu, který prokázal také snížení rizika CMP a přiznivý vliv na srdeční selhání (studie ALLHAT), u HCTZ a u indapamidu, u něhož je k dispozici velké množství dat dokládajících jeho přínos u široké škály pacientů včetně diabetiků (ADVANCE), pacientů vysokého věku (HYVET) Či pacientů po CMP léčených kombinací indapamidu s perindoprilem (PROGRESS).

\section{Jsou všechna diuretika rovnocenná?}

Chlortalidon prokázal svůj prrínos ve starších studiích s pacienty, kteři nebyli léčeni veškerou aktuálně doporučenou KV preventivní terapií. V ČR je hưře dostupný pouze ve fixní kombinaci a ve vyšší dávce. HCTZ je součástí raady fixních kombinací antihypertenziv. Jeho nevýhodou ale může být kratši poločas a obava z potenciálně zvýšeného rizika maligních kožních nádorů. U thiazidových diuretik může být někdy obavou aktivace RAS nebo zhoršení kompenzace diabetu prostřednictvím navozené hypokalemie. Týká se to ale spíše pacientů s diabetem léčených vysokou dávkou nebo kombinací diuretik. Nízké dávky thiazidových a thiazidům podobných diuretik jsou metabolicky relativně šetrné.

Přímá porovnání diuretik ukazuji větší snížení TK při podávání indapamidu nebo chlortalidonu v porovnání s HCTZ (obr. 6) (13), navíc s lepší bezpečností. Indapamid je diuretikum s príznivým metabolickým profilem, dlouhým poločasem a dobrým účinkem na snížení TK. Má prokázanou metabolickou neutralitu, kdy např. ve studii LIVE v porovnání s enalaprilem neprokázal během 1 roku nepř́iznivý vliv na hladinu lipidů, glykemii či tělesnou hmotnost (14). V běžných dávkách podávaných $\checkmark$ léčbě hypertenze navíc nevykazuje riziko minerálových dysbalancí. K dispozici je $v$ širokém spektru dávek a také jako součást rozšiřující se nabídky fixních kombinací.

\section{Jak měřit krevní tlak a $\mathbf{v}$ době covidu zvláště?}

Správné měření TK nám umožní vyhnout se zbytečné léčbě pacienta bez hypertenze, ale také terapeutické inercii. Naměřené hodnoty TK jsou ovšem výrazně ovlivněny jeho velkou variabilitou.

Měření TK v ordinaci není optimální. Pacient je málokdy v klidu z důvodu kontaktu s lékařem, diskuze o zdravotních problémech či stresu ze samotného měření TK. Někdy není tonometr při měření ve správné pozici a pacient nemá opřenou paži, někdy může být nepřesně odečtena hodnota, nevhodně se používají prístroje pro domácí měření TK, automatické prístroje.

Ani domácí měření TK nebývá ideální, jak ukázaly rozdíly mezi hodnotami naměřenými za stejné období pacientem a digitálním prístrojem (15). Pacienti navíc často využívají nevalidované tonometry. Seznam prístrojů na měření TK v domácím prostředí nebo v ordinaci, které úspěšně prošly testováním včetně dalších podrobností, lze najít na https://www.stridebp.org (16). Pacienti musejí být také ráádně instruováni, jak si TK doma měřit. Přesto má domácí měření TK větši výpovědní hodnotu než měření TK v ordinaci.

S rizikem úmrtí z KV príčin ale nejlépe koreluje TK naměřený během 24hodinového monitorování (17).
Obr. 6. Porovnání thiazidům podobných diuretik s hydrochlorthiazidem při snižování krevního tlaku (13)

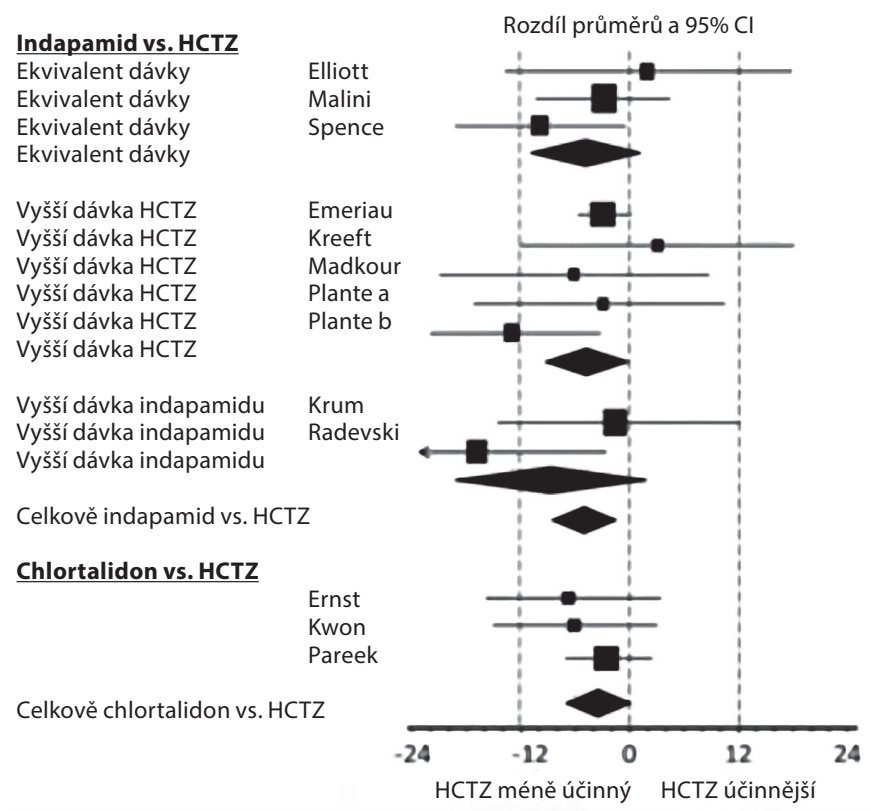

Telemedicína využívající přenos dat o hodnotách TK dosud nebyla zavedena do běžné praxe. Bylo ale doloženo, že použití domácího měření TK, telemetrie s přenosem dat na dálku a vzdálená úprava medikace bez nutnosti návštěvy pacienta $v$ ordinaci vede v porovnání s obvyklou péčí k poklesu TK o 4,7 mm Hg (18). Tento pokles TK není zanedbatelný, znamená zhruba 10\% snížení rizika CMP a 5\% snížení rizika koronárních příhod.

Opatření z důvodu covidu-19 přinesla rozvoj telemedicíny, kterou bychom mohli podle těchto dat společně s e-recepty využít ke zlepšení kompenzace TK. Je potřeba ale použivat validované technologie, integrované do informačních systémů zdravotnických zařizení.

\section{Závěr}

Přestože je jasně prokázáno, že pokles STK je spojen se snížením rizika KV prríhod, stále nedosahujeme optimální léčby hypertenze. Cílové průměrné hodnoty STK by se podle studií dokládajících nejnižší výskyt KV príhod měly pohybovat mezi 120-140 mm Hg. Léčba má být ale individualizovaná. Cílových hodnot je podle aktuálních doporučení třeba dosáhnout během 3 měsíců. V léčbě hypertenze je již iniciálně doporučena kombinace antihypertenziv, nejlépe blokátoru RAS a BKK, přičemž první volbou by měly být fixní kombinace prokazatelně zvyšující adherenci pacientů. V dalším kroku jsou vhodná diuretika, z nichž má dobrou účinnost, dlouhý poločas a prokázanou metabolickou šetrnost indapamid. Vzhledem k variabilitě TK je stále nevyřešeným problémem správné měření TK. Cestou ke zlepšení spolupráce pacientů a k dosažení cílových hodnot TK je větší uplatnění domácího měření krevního tlaku a telemedicíny.

Připravila MUDr. Zuzana Zafarova 


\section{LITERATURA}

1. Cífková R, Bruthans J, Wohlfahrt P, Krajčoviechová A, Šulc P, Jozífová M, Eremiášová L, Pudil J Linhart A, Widimský J Jr, Filipovský J, Mayer O Jr, Škodová Z, Poledne R, Stávek P, Lánská V. 30year trends in major cardiovascular risk factors in the Czech population, Czech MONICA and Czech post-MONICA, 1985-2016/17. PLoS One. 2020; 15(5): e0232845.

2. Ettehad D, Emdin CA, Kiran A, Anderson SG, Callender T, Emberson J, Chalmers J, Rodgers A Rahimi K. Blood pressure lowering for prevention of cardiovascular disease and death: a systematic review and meta-analysis. Lancet. 2016; 387(10022): 957-967.

3. Williams B, Mancia G, Spiering W, Agabiti Rosei E, Azizi M, Burnier M, Clement DL, Coca A, de Simone G, Dominiczak A, Kahan T, Mahfoud F, Redon J, Ruilope L, Zanchetti A, Kerins M, Kjeldsen SE, Kreutz R, Laurent S, Lip GYH, McManus R, Narkiewicz K, Ruschitzka F Schmieder RE, Shlyakhto E, Tsioufis C, Aboyans V, Desormais I; ESC Scientific Document Group. 2018 ESC/ESH Guidelines for the management of arterial hypertension. Eur Heart J. 2018; 39(33): 3021-3104.

4. Julius S, Kjeldsen SE, Weber M, Brunner HR, Ekman S, Hansson L, Hua T, Laragh J, McInnes GT, Mitchell L, Plat F, Schork A, Smith B, Zanchetti A; VALUE trial group. Outcomes in hypertensive patients at high cardiovascular risk treated with regimens based on valsartan or amlodipine: the VALUE randomised trial. Lancet. 2004; 363(9426): 2022-2031.

5. Xu W, Goldberg SI, Shubina M, Turchin A. Optimal systolic blood pressure target, time to intensification, and time to follow-up in treatment of hypertension: population based retrospective cohort study. BMJ. 2015; 350: h158.

6. Böhm M, Schumacher H, Teo KK, Lonn EM, Mahfoud F, Mann JFE, Mancia G, Redon J, Schmieder RE, Sliwa K, Weber MA, Williams B, Yusuf S. Achieved blood pressure and cardiovascular outcomes in high-risk patients: results from ONTARGET and TRANSCEND trials. Lancet 2017; 389(10085): 2226-2237

7. Wald DS, Law M, Morris JK, Bestwick JP, Wald NJ. Combination therapy versus monotherapy in reducing blood pressure: meta-analysis on 11,000 participants from 42 trials. Am $J$ Med. 2009; 122(3): 290-300.

8. Dezii CM. A retrospective study of persistence with single-pill combination therapy vs. concurrent two-pill therapy in patients with hypertension. Manag Care. 2000; 9(9 Suppl): 2-6. 9. Vrijens B, Vincze G, Kristanto P, Urquhart J, Burnier M. Adherence to prescribed antihypertensive drug treatments: longitudinal study of electronically compiled dosing histories. BMJ. 2008; 336(7653): 1114-1117.

10. Gradman AH, Parisé H, Lefebvre P, Falvey H, Lafeuille MH, Duh MS. Initial combination the- rapy reduces the risk of cardiovascular events in hypertensive patients: a matched cohort study. Hypertension 2013; 61(2): 309-318.

11. Kjeldsen SE, Oparil S, Narkiewicz K, Hedner T. The J-curve phenomenon revisited again: SPRINT outcomes favor target systolic blood pressure below $120 \mathrm{mmHg}$. Blood Press 2016; 25(1): 1-3.

12. Jamerson KA. Avoiding Cardiovascular events through Combination therapy in Patients Living with Systolic Hypertension Trial. The first hypertension trial comparing the effects of two fixed-dose combination therapy regimens on cardiovascular events: Avoiding Cardiovascular events through Combination therapy in Patients Living with Systolic Hypertension (ACCOMPLISH). J Clin Hypertens (Greenwich). 2003; 5(4 Suppl 3): 29-35.

13. Burnier M, Bakris G, Williams B. Redefining diuretics use in hypertension: why select a thiazide-like diuretic? J Hypertens. 2019 Aug; 37(8): 1574-1586.

14. Gosse P, Sheridan DJ, Zannad F, Dubourg O, Guéret P, Karpov Y, de Leeuw PW, Palma-Gamiz $J$, Pessina A, Motz W, Degaute JP, Chastang C. Regression of left ventricular hypertrophy in hypertensive patients treated with indapamide SR $1.5 \mathrm{mg}$ versus enalapril $20 \mathrm{mg}$ : the LIVE study. J Hypertens 2000; 18(10): 1465-1475.

15. Mengden T, Hernandez Medina RM, Beltran B, Alvarez E, Kraft K, Vetter H. Reliability of reporting self-measured blood pressure values by hypertensive patients. Am J Hypertens. 1998; 11(12): 1413-1417.

16. Parati G, Stergiou GS, Asmar R, Bilo G, de Leeuw P, Imai Y, Kario K, Lurbe E, Manolis A, Mengden T, O'Brien E, Ohkubo T, Padfield P, Palatini P, Pickering TG, Redon J, Revera M Ruilope LM, Shennan A, Staessen JA, Tisler A, Waeber B, Zanchetti A, Mancia G. ESH Working Group on Blood Pressure Monitoring. European Society of Hypertension practice guidelines for home blood pressure monitoring. J Hum Hypertens 2010; 24(12): 779-785.

17. Sega R, Facchetti R, Bombelli M, Cesana G, Corrao G, Grassi G, Mancia G. Prognostic value of ambulatory and home blood pressures compared with office blood pressure in the general population: follow-up results from the Pressioni Arteriose Monitorate e Loro Associazioni (PAMELA) study. Circulation 2005; 111(14): 1777-1783.

18. McManus RJ, Mant J, Franssen M, Nickless A, Schwartz C, Hodgkinson J, Bradburn P, Farmer A, Grant S, Greenfield SM, Heneghan C, Jowett S, Martin U, Milner S, Monahan M, Mort S, Ogburn E, Perera-Salazar R, Shah SA, Yu LM, Tarassenko L, Hobbs FDR. TASMINH4 investigators. Efficacy of self-monitored blood pressure, with or without telemonitoring, for titration of antihypertensive medication (TASMINH4): an unmasked randomised controlled trial. Lancet 2018; 391(10124): 949-959. 